\title{
HAROLD HENRY ROWLEY
}

Professor H. H. Rowley was one of the most prolific of Old Testament scholars in this century and one of those who was most honoured and respected, both for himself and for the quality of his work, by a world-wide circle of colleagues and friends; and his death on 4 October 1969 was a deep loss to scholarship, although a long and painful illness had warned that the end could not be long delayed.

Rowley lived for his work and seemed happiest with a bundle of galleys in his hand or the organization of an editorial project on his table. The present writer, on the occasion of his last personal visit a few weeks before Rowley's death, found him in bed in Cheltenham Hospital, with a thousand pages of proofs by his bedside. His scholarship was marked by its careful interest in, and registration of, the opinions of others ; he was not one of those who forge ahead with their personal notions while ignoring previous work on the subject, nor was he one to dismiss any man's view without solid reason, carefully stated. Indeed, some of his writing went almost to excess in the degree to which it annotated the opinions held by men infinitely below his own class. This work of annotation was supported by Rowley's own carefully compiled indexes and systems of cross-reference.

Primarily he was an Old Testament scholar, and it was as such that he received his greatest recognition. Much of his work took the form of judicious surveys of the état des travaux in some difficult and disputed part of the field. The subjects he undertook, though often tangled and criss-crossed by a bewildering variety of theories, were never other than central : Rowley was not one for the marginal note or the discovery of remote minutiae. Distinguished contributions were made on the Book of Daniel, on the history of the period from Joseph to Joshua, on the contribution of Moses, on Apocalyptic, and on the Dead Sea Scrolls, to name only a few. On the linguistic side his main contribution was one of his first published works, devoted to Old Testament Aramaic. He lived through the rise and the apogee of the 'Biblical theology' movement and wrote significant works on the unity, authority, and relevance of the Bible and the field of Old Testament theology. His editorial work was of even greater scope and included almost every kind of Biblical study.

His work in religion and theology went even farther afield. He was an active churchman, as witnesses his appointment as President of the Baptist Union, and his career had begun with a period of missionary and educational service in China. This had effects in his later academic work, in his interest in the history of religions, and in comparisons he published between religious phenomena in Israel and in China. New Testament studies, general theology, and even church history did not lie beyond his purview, as he showed in his reviewing and editing. Of the translations of foreign theological works which appeared in English in the last decades, many might well have been almost unintelligible but for Rowley's careful-and often insufficiently acknowledged-corrections.

His interest in the literature of his subject was prodigious, and he built up a 


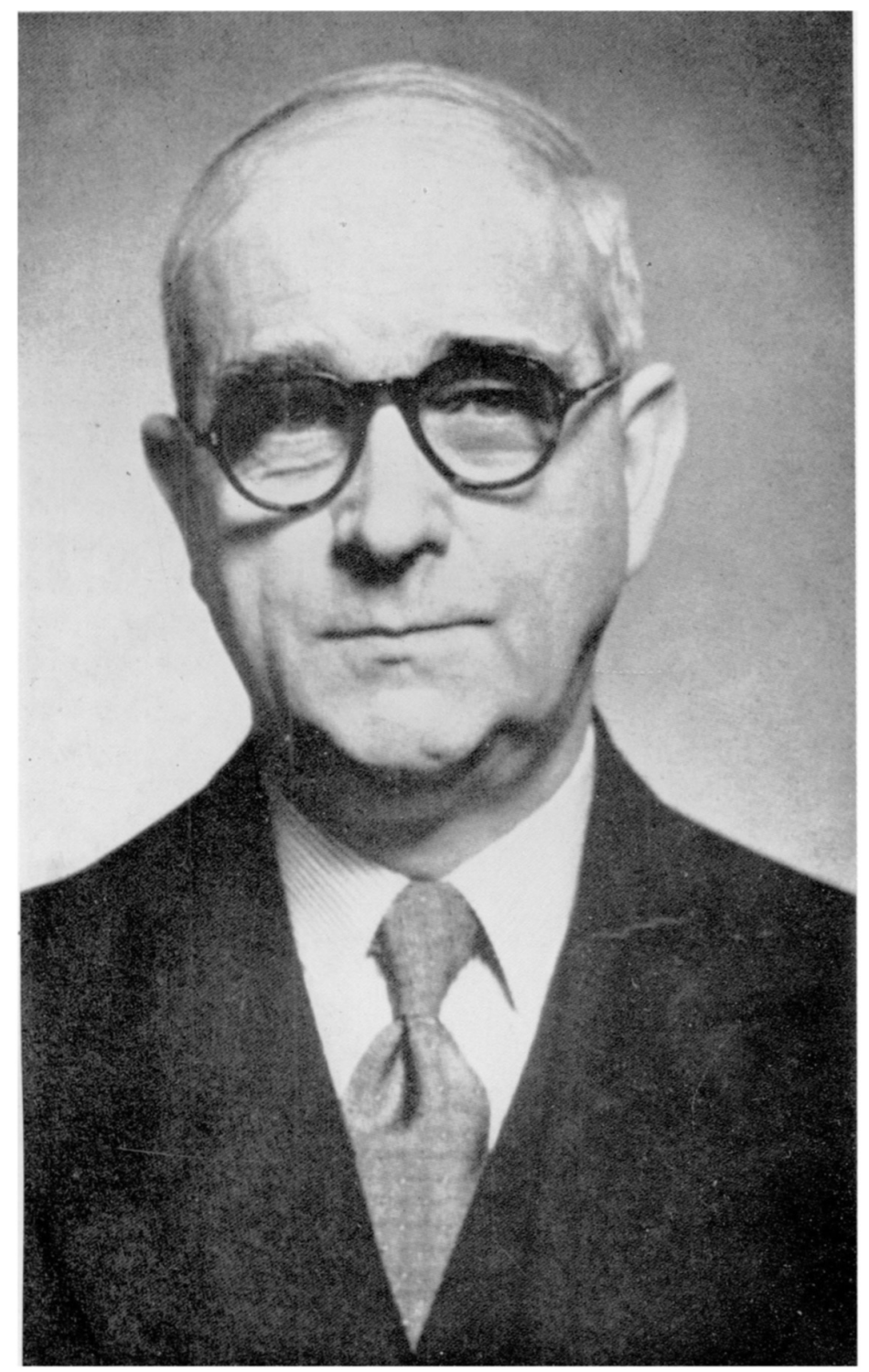

Harold Henry Rowley

BSOAS. XXXIII] 
personal library such as most major institutions might have been proud to possess. He reviewed a great deal, and it is believed that many eminently fair and objective reviews in the Times Literary Supplement were from his pen. He played a major part in the initiation and guidance of that extremely successful project, the Book List of the Society for Old Testament Study, and he was a regular contributor to the review sections of many periodicals. Though less a Semitist himself than an Old Testament scholar, he played a major part in the initiation of the Journal of Semitic Studies and his interest in reviewing has continued to be reflected in that journal.

Rowley was a stalwart supporter of academic societies in his field. He not only held important office in the Society for Old Testament Study and in the corresponding international organization, but he carried on a work of personal correspondence with other scholars which did much to advance mutual understanding, and he is remembered especially in Europe for his part in re-establishing the personal and scholarly links which had been severed by war. He was honoured by a Fellowship of the British Academy and by corresponding foreign fellowships and memberships, to say nothing of honorary degrees both at home and abroad, too numerous to mention. He was an Honorary Fellow of the School of Oriental and African Studies.

H. H. Rowley was born in Leicester on 24 March 1890, and the main steps in his academic career, after his beginnings in China, were firstly in Cardiff, secondly in Bangor, and thirdly in Manchester, where he was Professor from 1945 until his retirement in 1959 (Chair of Semitic Languages and Literatures, 1945-9, renamed as Hebrew Language and Literature from 1949). After his retirement he lived in Stroud.

Rowley's scholarship could be most fairly characterized less for its originality than for its deep experience of the world of scholarly opinion and its judicious weighing both of the evidence of the texts themselves and of the diversities of views which have been held about them. He will be remembered as one of the most imposing figures of British Semitic and Old Testament scholarship in the present century.

JAMES BARR 